\author{
MONIKA BINIECKA ${ }^{1,2}$, JAN WOLNIK ${ }^{1,2}$, JÓZEF DULAK ${ }^{2}$ \\ ${ }^{1}$ Kardio-Med Silesia \\ Marii Skłodowskiej-Curie 10C, 41-800 Zabrze \\ ${ }^{2}$ Department of Medical Biotechnology \\ Faculty of Biochemistry, Biophysics and Biotechnology \\ Jagiellonian University \\ 7 Gronostajowa St., 30-387 Krakow \\ e-mail: monika.biniecka@uj.edu.pl
}

\title{
THE FUNDAMENTAL DISCOVERIES IN OXYGEN SENSING: IMPLICATIONS FOR HEART DISEASES AND CARDIOMYOCYTES MATURATION
}

\section{INTRODUCTION}

Oxygen is the terminal electron acceptor of the electron transport chain (ETC) and is essential for oxidative phosphorylation (OXPHOS) and for cell survival. In respiring cells, the maintenance of bioenergetic homeostasis requires a constant supply of molecular oxygen. When the oxygen requirements of a cell exceed the vascular supply, it can lead to a metabolic imbalance between supply and demand for oxygen defined as hypoxia.

Hypoxia is a feature of both physiological and pathological conditions. The levels of oxygen vary under physiological conditions, ranging for instance from $150 \mathrm{~mm} \mathrm{Hg}$ (15\%) in the lung, to $100 \mathrm{~mm} \mathrm{Hg}(13 \%)$ in arterial blood but $40 \mathrm{~mm} \mathrm{Hg}(\sim 5 \%)$ in the liver. As the normal oxygen pressure (PO2) varies between different tissues, there is no clear-cut threshold separating normoxia from hypoxia and the definitions of mild, moderate, and severe hypoxia are not clearly established. However, 8-10 $\mathrm{mm} \mathrm{Hg} \mathrm{(} \mathrm{1 \% )} \mathrm{is} \mathrm{estimated} \mathrm{to}$ represent a critically low level of oxygen detected in tumours and chronically inflamed disorders, cardiovascular defects, as well as infected or ischaemic tissue environment. A breakthrough in our understanding of cellular responses to changes in oxygen levels was the discovery of hypoxia inducible factors (HIFs) and their regulation by the von Hippel-Lindau (VHL) tumour suppressor protein (pVHL) and prolyl hydroxylases
(PHDs). This finding provided a molecular framework for how changes in oxygen levels can affect transcriptional responses and provides therapeutic targets for treatment of pathological states.

In this Review, we briefly discuss the sequence of key discoveries made by the 2019 Nobel laureates, which led to the elucidation of the oxygen sensing and signaling pathway. We also discuss the role of hypoxia signaling in the pathogenesis of cardiovascular diseases, as well as other pathological settings such as inflammation and tumour. Lastly, we will focus on the effects of hypoxia and energy metabolism on differentiation and maturation of cardiomyocytes derived from induced pluripotent stem cells (iPSC-CMs).

\section{FUNDAMENTAL DISCOVERIES IN HYPOXIA RESPONSE}

The 2019 Nobel Prize for Physiology or Medicine was awarded to Professors Sir Peter J. Ratcliffe (University of Oxford, UK), Gregg L. Semenza (Johns Hopkins University in Baltimore, Maryland), and William G. Kaelin Jr. (Dana-Farber Cancer Institute, Institute in Boston, Massachusetts) for describing how cells sense and respond to changing oxygen levels by switching genes on and off. Each physician-scientist had different clinical observation and applied miscellaneous biochemical approaches to explore cellular hypoxic responses. The history 
of uncovering hypoxia response began in the 1990s with a keen focus on fundamental aspects of human physiology driven by a deep interest in basic human biology.

Semenza, a pediatric geneticist, investigated the triggers responsible for the synthesis of erythropoietin, a hematopoietic growth factor secreted by the liver and kidney that stimulates the generation of red blood cells in the bone marrow. His team identified a sequence-specific binding site named hypoxia-response element (HRE) for a transcription factor in the 3' flanking region of the human erythropoietin gene (EPO). Further investigations have revealed that the specific HIF-1-binding site is ubiquitous in the human genome and was found at many locations, including also the 5'-flanking regions and introns of many genes. Subsequently, the team purified hypoxia inducible factor 1 (HIF-1), a heterodimeric transcription factor, composed of two subunits, the HIF-1a (or its analogs HIF-2a and HIF-3a) and HIF-1 $\beta$ subunits. HIF-1 was shown to induce a wide number of other genes essential for cellular and systemic response to hypoxia, as well as for cell survival and homeostasis (MOSLEHI and RATHMELL 2020). Meanwhile, Kaelin, an internist and oncologist, found that a gene called VHL also seemed to be involved in how cells respond to oxygen. He was studying a genetic syndrome called von Hippel-Lindau's disease. Families with the disease carry mutations in $V H L$ and the condition raises the risk of certain cancers. The protein product of $V H L$ forms a complex involved in the ubiquitination and degradation of specific proteins and the correct assembly of the VHL complex plays a key role in regulation of hypoxia-inducible genes (LEE et al. 2020). However, a crucial study linking observations made by Semenza and Kaelin came from Ratcliffe, a nephrologist who investigated the mechanism of oxygen sensing and systemic erythropoietin production by kidneys. He showed the regulation of $\mathrm{pVHL}$ by HIF-1a, as well as proved the ability of many cells to sense hypoxia and promote EPO transcription via the HRE. Overall, it indicated that the protein expressed by $V H L$ interacts with a component of HIF, turning off responses to low-oxygen conditions by marking the HIF component for destruction once oxygen levels rise (ZHANG et al. 2019). It should be also stressed that HIF-1a and HIF-2a share many transcriptional targets, however certain genes and processes might be differentially regulated. While anaerobic glycolysis seems to be primarily controlled by HIF-1a, HIF-2a has emerged as the transcription factor that plays a key role in EPO synthesis in the liver and kidney and regulates iron uptake and utilization (LOBODA et al. 2010, 2012).

\section{FUNCTIONAL DOMAINS OF HIF ISOFORMS}

Hypoxia-inducible factors include four major isoforms such as oxygen-sensitive HIF-1a, HIF-2a and HIF-3a and oxygen-insensitive HIF-1ß (Fig. 1). HIF-1a is an oxygen sensitive subunit which expression is induced under hypoxic conditions. Contrary,

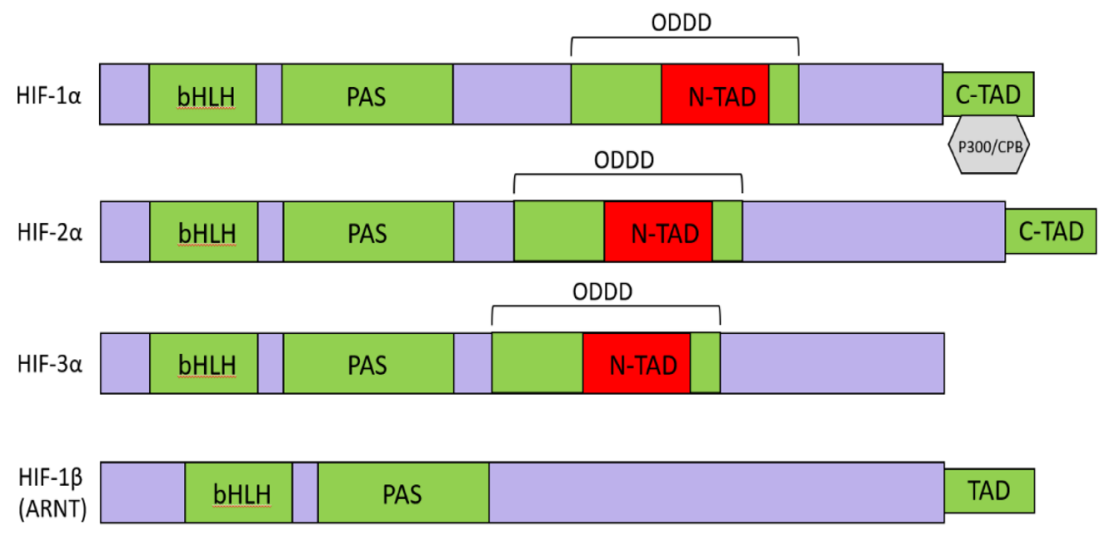

Fig. 1. Functional domains of HIF isoforms. The HIF system consists of three oxygen-sensitive a subunits, HIF-1a, HIF-2a and HIF-3a and oxygen-insensitive HIF-1 $\beta$ subunit. All isoforms possess a basic helix-loop-helix (bHLH) domain that binds DNA and PAS domain for heterodimerization. HIFa isoforms contain an oxygen-dependent degradation domain (ODDD) that mediates oxygen stability and an N-terminal transactivation domain (N-TAD) within the ODDD. The C-terminal transactivation domain (C-TAD), which is not found in HIF-3a, contains an asparaginyl residue implicated in transcriptional activation. 
HIF-1 $1 \beta$ is constitutively expressed and is also known as aryl hydrocarbon nuclear translocator (ARNT) as it was identified as a heterodimeric partner of aryl hydrocarbon receptor (AhR). HIF-1a (or its analogs HIF$2 \alpha$ and $\mathrm{HIF}-3 \mathrm{a})$ and $\mathrm{HIF}-1 \beta$ subunits contain the basic-helix-loop-helix (bHLH) and two nuclear proteins found in Drosophila (Per and Sim, PAS). Importantly, bHLH-PAS motifs allow heterodimer formation between HIF-1a and HIF-1 $\beta$ and for binding to the HRE-DNA sequence on the target genes. The HIF-1a subunit also consist transactivation domains (TAD) named NH2-terminal (N-TAD) and $\mathrm{COOH}$-terminal (C-TAD) that are responsible for HIF-1a transcriptional activity. While C-TAD interacts with co-activators such as $\mathrm{CBP} / \mathrm{p} 300$ to modulate gene transcription of HIF-1a under hypoxia, N-TAD is essential for HIF-1a stabilization (DENGLER et al. 2014). The difference between HIF$1 \mathrm{a}$ and HIF-2a is found mainly within the $\mathrm{N}-\mathrm{TAD}$ and is related to targeting specific genes. In turn, C-TAD is homologous between HIF-1a and HIF-2a and mediates the expression of common target genes in these two isoforms. Furthermore, an oxygen dependent degradation domain (ODDD) overlapping N-TAD is present only in all HIF-a subunits and consists of specific proline residues (Pro402 and Pro564 in HIF-1a and Pro405 and Pro531 in HIF-2a) which are hydroxylated in normal oxygen concentration by a special group of prolyl hydroxylases. HIF-3a is the most distantly related and is less studied. It shows a high similarity to HIF-1a and HIF-2a in the bHLH and PAS domains, but it lacks the C-TAD domain. It is also able to dimerize with HIFß subunits, and the formed heterodimer recognizes the HRE on the promoter of target genes (LOBODA et al. 2010, RAVENNA et al. 2016). HIF$3 a$ is postulated to act as a negative regulator of HIF-mediated transcription. In mice, a splicing variant called inhibitory PAS (IPAS) domain protein was found as a dominantnegative regulator of the HIF gene expression involved in regulation of angiogenesis and maintenance of an avascular phenotype (MAKINO et al. 2001). Further studies demonstrated HIF-3a in the human kidney and its ability to suppresses hypoxia-inducible HIF-mediated gene expression in the kidney (HARA et al. 2001).

\section{THE ROLE AND REGULATION OF HIF PROLYL HYDROXYLASES}

Prolyl hydroxylase domain protein family plays a major role in HIF regulation. These proteins belong to a family of a-ketoglutarate/2-oxoglutarate-dependent, non-haem iron-binding dioxygenases. The presence of PHD proteins was firstly discovered in C. elegans (TAYLOR 2001) and since then described in many different species including rat (EPSTEIN et al. 2001), Dictyostelium (WEST et al. 2007), Drosophila melanogaster (BRUICK and MCKNIGHT 2001), Schizosaccharomyces pombe (HUGHES and ESPENSHADE 2008) or even photosynthetic organism such as Chlamydomonas reinhardtii (KESKIAHO et al. 2007). As reviewed (NGUYEN and DURÁN 2016), in mammals three main prolyl hydroxylases isoforms are coded by three different genes: EGLN1 (encoding PHD2), EGLN2 (encoding PHD1) and EGLN3 (encoding PHD3). Additionally, fourth protein TM-HIF-P4H was discovered in endoplasmic reticulum, however its properties are similar not only to HIFs prolyl hydroxylases but also to collagen prolyl hydroxylases (OEHME et al. 2002). Three main isoforms are present in all tissues, however expression levels vary between different organs. PHD1 is highly expressed in testes, brain, kidney, heart and liver, while PHD3 is mostly present in the heart (CIOFFI et al. 2003). PHD2 appears to be the main HIF1a regulator and key oxygen sensor (BERRA et al. 2003). PHDs are involved in many processes and pathways, including mammalian target of rapamycin (mTOR) (DURÁN et al. 2012), nuclear factor-kB (NF-kB) (CUMMINS et al. 2006), epidermal growth factor receptor (EGFR) (GARVALOV et al. 2014) and erythropoietin receptor signaling (KAPITSINOU et al. 2010, HEIR et al. 2016). Furthermore, some PHDs are implicated in regulation of transcription, translation and apoptosis. Nevertheless, the main role of PHDs is the cellular regulation of HIF concentrations. PHDs targets HIF-1a transcription and in the presence of oxygen hydroxylates it in oxygen dependent degradation domain which results in binding of HIF-1a to von Hippel-Lindau factor and leads to ubiquitination of the complex and therefore, degradation of HIF-1a (BERRA et al. 2006).

PHD regulation involves three main groups: oxygen, co-substrates like 2-oxoglutarate and co-factors such as $\mathrm{Fe}^{2+}$ ions. Study showed that one atom of $\mathrm{O}_{2}$ molecule may oxidize and decarboxylate 2-oxoglutarate generating $\mathrm{CO}_{2}$ and succinate, while the second atom is used for hydroxylation of a proline in HIF-1a (MCNEILL et al. 2002). PHD enzymes in their catalytic side possess a conserve two-histidine, one carboxylate motif which allows iron binding. Iron ions are necessary for other co-substrates and oxygen binding (SCHOFIELD and RATCLIFFE 2004). Low oxygen levels promote reactive oxygen species (ROS) production 
Table 1. Influence of different intercellular factors on PHD activities.

\begin{tabular}{|c|c|c|c|c|}
\hline $\begin{array}{l}\text { Role for PHD } \\
\text { enzyme }\end{array}$ & Substance & Main function in PHD regulation & $\begin{array}{l}\text { Level of PHD } \\
\text { activity }\end{array}$ & $\begin{array}{l}\text { Level of HIF } 1 \\
\text { concentration }\end{array}$ \\
\hline main substrate & dioxygen & $\begin{array}{l}\text { donor of oxygen atoms required } \\
\text { for hydroxylation }\end{array}$ & increased & decreased \\
\hline co-factor & $\mathrm{Fe}^{2+}$ & $\begin{array}{l}\text { allows binding of other substra- } \\
\text { tes and factors }\end{array}$ & increased & decreased \\
\hline inhibitor & $\begin{array}{l}\text { reactive oxygen spe- } \\
\text { cies }\end{array}$ & $\mathrm{Fe}^{2+}$ oxidation & decreased & increased \\
\hline inhibitor & nitric oxide & $\mathrm{Fe}^{2+}$ chelation & decreased & increased \\
\hline co-substrate & 2-oxyglutarate & electron donor & increased & decreased \\
\hline $\begin{array}{l}\text { competitive in- } \\
\text { hibitor }\end{array}$ & $\begin{array}{l}\text { succinate, fumarate, } \\
\text { citrate, isocitrate }\end{array}$ & $\begin{array}{l}\text { competitive inhibition toward } \\
2 \text {-oxoglutarate in the absence of } \\
\text { enzymes processing those sub- } \\
\text { stances }\end{array}$ & decreased & increased \\
\hline unknown & ascorbate & $\begin{array}{l}\text { likely prevents iron ions oxida- } \\
\text { tion }\end{array}$ & increased & decreased \\
\hline
\end{tabular}

which oxidize $\mathrm{Fe}^{2+}$ to $\mathrm{Fe}^{3+}$. Iron in its third oxidation state is no longer able to bind to PHDs which results in inhibition of its activities (CHANDEL et al. 2000). 2-oxoglutarate (aKG) is produced mostly in mitochondria and is an intermediate in tricarboxylic acid cycle (TCA). Additionally, it also serves as an electron donor for prolyl hydroxylation and coordinates iron binding in the active center of PHD (EPSTEIN et al. 2001). Other substances involved in TCA cycle, such as fumarate, succinate, citrate, isocitrate were reported to decrease PHD activity in a competitive inhibition fashion. Regulation of PHDs activity is described below and summarized in Table 1.

\section{HYPOXIA-INDUCED SIGNALING UNDER NORMOXIC AND HYPOXIC CONDITIONS}

Hypoxia activates the hypoxia signaling pathway, which is predominantly governed by hypoxia stabilization of HIF - master regulator of oxygen homeostasis (Fig. 2). Under normoxic conditions, when oxygen is ample, the proline residues of HIF-a subunits (P402/ P564) are hydroxylated by oxygendependent prolyl-4-hydroxylases. Von Hippel-Lindau protein, an E3 ubiquitin ligase, binds to the hydroxylated HIF-a and acts as a substrate recognition component of the E3 ubiquitin ligase complex, which leads to the proteosomal degradation of HIF protein. The asparaginyl residue (Asn-803) of HIF-a subunits is also hydroxylated by factors inhibiting HIFs (FIHs), which inhibits the binding of HIF with coactivators p300/CREB-binding protein. During hypoxia, however, the activity of PHDs and FIHs are suppressed, resulting in the accumulation and activation of HIF-1a, which can then translocate into the nucleus and associate with HIF-1ß. The heterodimeric HIF-1a: HIF-1 $\beta$ transcription factor complex then locates to the hypoxiaresponsive elements of its target genes, resulting in their transcriptional upregulation (LEE et al. 2020).

Functional activities of HIFs have been greatly investigated in the past decades and revealed the involvement of hypoxia in the regulation of a wide number of physiological and pathophysiological processes, including inflammation, angiogenesis, energy metabolism, tumor metastasis, cell differentiation and apoptosis. Interestingly, HIF-1a and HIF-2a show different pattern of tissue distributions. While HIF-1a is ubiquitously expressed in the body, expression of HIF-2a seems to be more strictly localized within specific tissues. Some in situ studies reported HIF-1a RNA to be widespread in all tissues other than peripheral blood leukocytes, and HIF-2a RNA to be greatly present in vascular tissues such as lung, heart, placenta, and kidney (TALKs et al. 2000). Furthermore, the tumor cells of solid tumors of breast, bladder, brain, colon, ovarian, pancreatic, prostate and renal carcinomas, show nuclear expression of HIF-1a and HIF2a. In addition, strong expression of HIF-2a was detected in the subset of tumor-associated macrophages, even in the absence of any tumor cell expression. Lower expression 


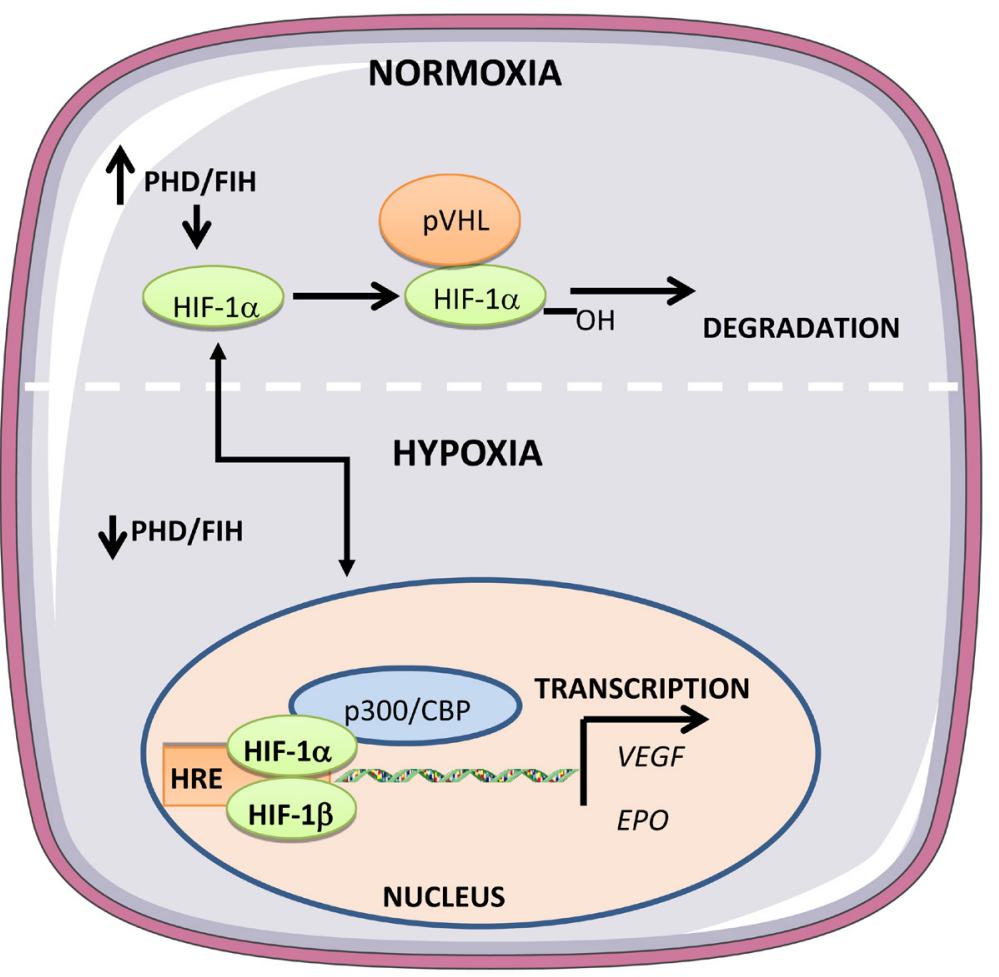

Fig. 2. Hypoxia-inducible factor (HIF) regulation during normoxia and hypoxia. In oxygenated conditions, HIF is hydroxylated on proline residues by prolyl-4-hydroxylases (PHDs) and polyubiquitinated by the von Hippel-Lindau protein (pVHL), leading to degradation of HIF. Under hypoxia, HIF is stabilized and translocated into the nucleus, where it binds to its dimerization partner HIF-1 $\beta$ and enhances the transcription of HIF target genes, e.g. vascular endothelial growth factor (VEGF) and erythropoietin (EPO).

of HIF-2a was found in other stromal cells within the tumors and in normal tissue adjacent to tumor margins (TALKS et al. 2000, LAGORY and GIACCIA 2016, LAITALA and ERLER 2018).

\section{THE EFFECT OF HYPOXIA AND ITS THERAPEUTIC TARGETING IN HEART DISEASES}

Since the discovery of HIF, many studies have been performed proving the role of hypoxia signaling pathway in driving many human diseases. Below, we will briefly discuss the current knowledge of the hypoxia signaling in heart diseases, such as ischemic and valvular heart disease, congestive heart failure as well as in some inflammatory diseases and tumors. We will also indicate the potential HIF therapeutic targets that may serve as novel treatment options for heart diseases.

Ischemic heart disease is caused by the narrowing of a major coronary artery or the rupture of coronary plaque, that results in reduced blood flow or limited oxygen supplement to the cardiac muscles. It causes decrease in ATP production, dysfunction of pumps, and cell death within the ischemic parts of the heart. Some studies described cardio-protective mechanisms of HIF stabilization during acute myocardial ischemia and reperfusion injury that results in tissue tolerance to ischemic injury. HIF-1a was shown to increase in peri-infarct areas of patients after acute myocardial infarction or during acute myocardial ischemia (LEE et al. 2000). Likewise, HIF-2a was elevated in the mouse heart after coronary artery occlusion following exposure to hypoxia $\left(8 \% \mathrm{O}_{2}\right)$ (WIESENER et al. 2003). In addition, activation of HIF-1 in murine hearts attenuates reperfusion injury via inducible nitric oxide synthase (iNOS)-dependent pathway (NATARAJAN et al. 2006) and heme oxygenase 1 (HO-1) is induced by the activation of HIF1a, reducing proinflammatory cytokine production in rabbit model of ischemia reperfusion injury (IRI) (OCKAILI et al. 2005). Similarly, HIF-2a is also considered as key transcription factor in conveying cardio-protection during ischemia reperfusion injury. Myocyte-specific HIF-2a deletion enhances cardioprotection in myocardial IRI inducing 
expression of myocardial epithelial growth factor amphiregulin (AREG), which increases myocardial ischemia tolerance (KoEPPEN et al. 2018). HIF-1 also plays a critical role in the transcriptional coordination of adaptive responses elicited by ischemic preconditioning (IPC) of the murine heart. IPC is an experimental technique in which tissues are rendered resistant to the deleterious effects of ischemia/reperfusion injury by prior exposure to brief, repeated periods of vascular occlusion. Knockdown of HIF-1a abrogated the protective effects of IPC, while the knockdown of PHD2 or pharmacological activation of HIF by dimethyloxalylglycine (DMOG) - a competitive PHD inhibitor - mimicked the effects of IPC (ECKLE et al. 2008). Similarly, HIF may play a role in ischemic postconditioning (IPostC), which refers to a series of brief ischemia and reperfusion cycles applied immediately at the site of the ischemic organ after reperfusion, results in reduced infarction in myocardial ischemia along with increased HIF1a expression, as well as reduced activity of caspase- 3 and apoptosis. Subsequently, PostC-induced reduction in infarct size and expression in HIF-1a was further pharmacologically elevated by pretreatment with DMOG (ZHAO et al. 2010).

Congestive heart failure $(\mathrm{CHF})$ is defined as the failure of the heart to maintain proper contractility, leading to ineffective blood flow to peripheral organs and symptoms of fatigue and dyspnea. CHF results from other conditions that weaken the heart muscle including coronary artery disease, myocardial infarction, cardiomyopathy and hypertension. Pressure overload and increased heart rate cause elevated burden to the myocardium and aggravates the balance between oxygen demand and supply, resulting in chronically activated hypoxic responses in the heart (GIORDANO 2005). Interestingly, contrary to the acute protective roles of HIF in ischemic heart disease, chronic HIF expression was found to a have deleterious impact. In a cardiac-specific HIF-1a transgenic mice, constitutive expression of HIF1a lead to changes in capillary area associated with decreased expression of sarcoplasmic/endoplasmic reticulum calcium ATPase and altered calcium handling and the spontaneous development of cardiac hypertrophy with age. There was also a shift in the cardiac metabolism towards glycolysis with a net increase in glucose uptake (HöLSCHER et al. 2012). Another study examining the role of cardiac angiogenesis and p53 accumulation in the process of cardiac hypertrophy demonstrated HIF-1-dependent induction of angiogenic factors, while the inhibition of angiogenesis prevented the development of cardiac hypertrophy and induced systolic dysfunction. However, the accumulation of p53 from prolonged pressure overload inhibited the HIF-1a activity and impaired cardiac angiogenesis and systolic function, indicating an anti-angiogenic property of p53 transition from cardiac hypertrophy to heart failure (SANO et al. 2007). Conversely, little is known about the role of HIF-2a in the chronically activated hypoxic responses of the heart. One study investigated a mechanism underlying a critical and direct role of the adipocyte HIF-2a transcription factor in the development of adipose inflammation and pathological cardiac hypertrophy in VHL knockout mice. HIF activation in adipocytes resulted in overexpression of key cardiomyopathy-associated genes in adipose tissue, increased serum levels of several proinflammatory cytokines, while genetic deletion of HIF-2a rescued cardiac hypertrophy and abrogated adipose inflammation (Lin et al. 2013).

Valvular heart disease is characterized by damage to or a defect in one of the four heart valves - the mitral, aortic, tricuspid or pulmonary - and presented as narrowing or insufficiency to shut properly. It is driven by age-dependent degeneration of tissue, as well as by congenital defects or rheumatic heart disease. Hypoxia has been suggested to regulate vascular endothelial growth factor (VEGF) expression in developing heart valves and VEGF is a regulator of endothelial cell proliferation and its expression is important for the endothelial cells to undergo endothelial-mesenchymal transdifferentiation (EMT) (ARMSTRONG and BISCHOFF 2004). Tissue explant studies have shown that hypoxia decreases cardiac cushion EMT, an effect that was abrogated by addition of soluble vascular endothelial growth factor receptor 1 (VEGF-R1). In addition, VEGF expression was increased approximately 10 -fold in cardiac cushions under hypoxic conditions (DoR et al. 2003). These results suggest that fetal hypoxia may increase VEGF expression in the cushion-forming areas and inhibit EMT. Therefore, fetal hypoxia during cushion development might contribute to congenital cardiac defects in the cardiac valves and interatrial septum (ARMSTRONG and BisCHOFF 2004). Another study determined the effect of hypoxia on the regulation of mitral valve interstitial cells (MVICs) on the synthesis and secretion of extracellular matrix proteins. Hypoxia resulted in reduced production of total collagen, increased gene expression of matrix metalloproteinases- 1 and -9 (MMP1 and MMP9), but had no effect on 
MVIC viability, morphology, or phenotype (SALHIYYAH et al. 2017).

Based on the available reports, HIF seems to have contrary therapeutic effects on heart diseases (LEE et al. 2019). During acute hypoxic conditions, rapid stabilization of HIF cause a prompt expression of hypoxia-regulated target genes. The downstream genes include these related to proliferation, survival, metabolism and angiogenesis, providing cellular ischemic tolerance. Conversely, due to the long-term development and multiple background of chronic diseases, the exact role of hypoxia in the pathogenesis under chronic settings seems to be controversial. Study by HÖLSCHER et. al. (2012) showed that prolonged activation of HIF-1 over time aggravate heart failure and may drive the development of cardiomyopathy. The other study demonstrated restoration of cardiac dysfunction as a result of HIF-1a induced angiogenesis (SANO et al. 2007). In turn, treatment of wild-type mice with digoxin, which inhibits HIF-1a synthesis was associated with increased transforming growth factor beta (TGF- $\beta$ ) signaling and resulted in rapid cardiac failure and pathological remodeling (WEI et al. 2012). Pharmacologic activation of HIF by inhibition of PHD proteins is also an area of interest. Numerous papers have demonstrated the beneficial role of DMOG and has been shown to play an important role against ischemia-reperfusion myocardial injury. In mice, treatment with DMOG increased the expression of HIF-1a in the endothelium of coronary arteries accompanied by a significant improvement of coronary flow reserve and diastolic function. Furthermore, it altered endothelial metabolism by increasing glycolysis and reducing oxygen consumption. It provides a potential therapeutic strategy of induction of hypoxia tolerance for patients with diastolic dysfunction associated with coronary microvascular dysfunction ( $\mathrm{HE}$ et al. 2018).

\section{THE ROLE OF HYPOXIA IN INFLAMMATORY DISEASES AND TUMOUR}

Hypoxia and inflammation are co-existing events in a diverse range of pathological conditions, which include chronically inflamed and ischaemic tissues, as well as inflammation driven carcinogenesis (TAYLOR and COLGAN 2017). In these circumstances, tissue hypoxia leads to activation of the HIF pathway, which is a major transcriptional regulator of immune cell effector function. NF-kB pathway is also involved in the transcriptional regulation of immunity and controls multiple aspects of immune cell function following its activation by inflammatory stimuli. Furthermore, proinflammatory stimuli (e.g. cytokines) and signalling mediators (e.g. ROS) may change the profile of HIF responses contributing to the regulation of immunity and inflammation (LEE et al. 2020). Acute inflammation is characterized by the accumulation of large numbers of neutrophils and shifts in tissue energy metabolism. The impact of hypoxia in acute inflammation can be tissue dependent. While in the lung, hypoxic microenvironment increases neutrophils survival that may contribute to lung damage, in the intestinal mucosa hypoxia may play a role in the resolution of inflammation (SCHAIBLE et al. 2010, CAMPBELL et al. 2014).

In chronic inflammation hypoxia can be either pro-inflammatory or anti-inflammatory depending on cell/tissue type and circumstances. In inflammatory bowel disease (IBD), the intestinal mucosa is profoundly hypoxic due to the increased metabolic demands triggered by inflammatory cells and reduced vascular supply resulting from vascular dysfunction, which eventually cause tissue fibrosis. As a result, hypoxia of intestinal epithelial cell creates protection barrier through mechanisms involving HIF activated genes expressed in epithelial cell (GLOVER et al. 2016). In the chronically inflamed joint of rheumatoid arthritis, the efficiency of oxygen supply to the synovial tissue is poor due to the impaired synovial microvasculature. This is also associated with the increased energy demands of activated infiltrating immune cells and inflamed resident cells leads to hypoxic microenvironment and mitochondrial dysfunction. Finally, this favors an increase of reactive oxygen species, leading to oxidative damage which further promotes inflammation (FEARON et al. 2016).

Tumours are one of the best characterized pathological immunological conditions. Developing tumours outgrow the local blood supply leading to a profound hypoxia. It is well known that HIF induces proangiogenic factors, such as VEGF, which promotes tumour angiogenesis and induces tumour growth. It is associated with dysregulated "leaky" vasculature which provides a route by which tumour cells can leave the site the primary tumour development, enter the bloodstream and create metastases. In the tumour microenvironment hypoxia also regulates the functions of immune cell, which in turn plays a role in tumour progression, dissemination and suppression (UNWITH et al. 2015, PEtrova et al. 2018, Al TAMEEmi et al. 2019). 


\section{THE EFFECT OF HYPOXIA ON MITOCHONDRIAL BIOENERGETICS}

Cellular metabolism depends on the ratio of energy requirements and substrate availability. Molecular oxygen maintains intracellular bioenergetics and is consumed by many biochemical reactions. Mitochondria play a central role in the regulation of cellular bioenergetics and energy metabolism therefore regulate cellular stress responses (SolAini et al. 2010). The mitochondrial electron transport chain is the largest oxygen consumer for generation of ATP during oxidative phosphorylation. Hypoxia affect the activity of mitochondrial ETC at multiple levels, including the regulation of different ETC complexes and the availability of tricarboxylic acid cycle-reducing equivalents NADH and FADH (SolAINI et al. 2010). Under hypoxia, ETC activity is sustained by expression of the complex IV (cytochrome $c$ oxidase or COX), the terminal complex within the ETC, that donates four electrons to oxygen, producing two molecules of water. COX possess a high affinity for oxygen, therefore the ETC can function at severe hypoxia (anoxia), however prolonged hypoxia reduces functions of ETC. The activation of HIF-1 in response to reduced oxygen promotes the expression of genes involved in hypoxic cell metabolism. One of the most significant cellular adaptations to oxygen deprivation is increased glucose uptake and elevated glycolytic flux. It is driven by HIF-1-promoted activation of genes encoding glucose transporters (GLUTs) that facilitate the transport of glucose across the plasma membrane increasing cellular glucose concentration (Fig. 3) (FEARON et al. 2016). Intracellular glucose is metabolized by a numerous of HIF-dependent glycolytic enzymes. Elevated glycolysis generates pyruvate, which is largely converted to lactate by HIF-inducible lactate dehydrogenase A (LDHA). Furthermore, HIF-1a induces activity of pyruvate dehydrogenase kinase (PDK),

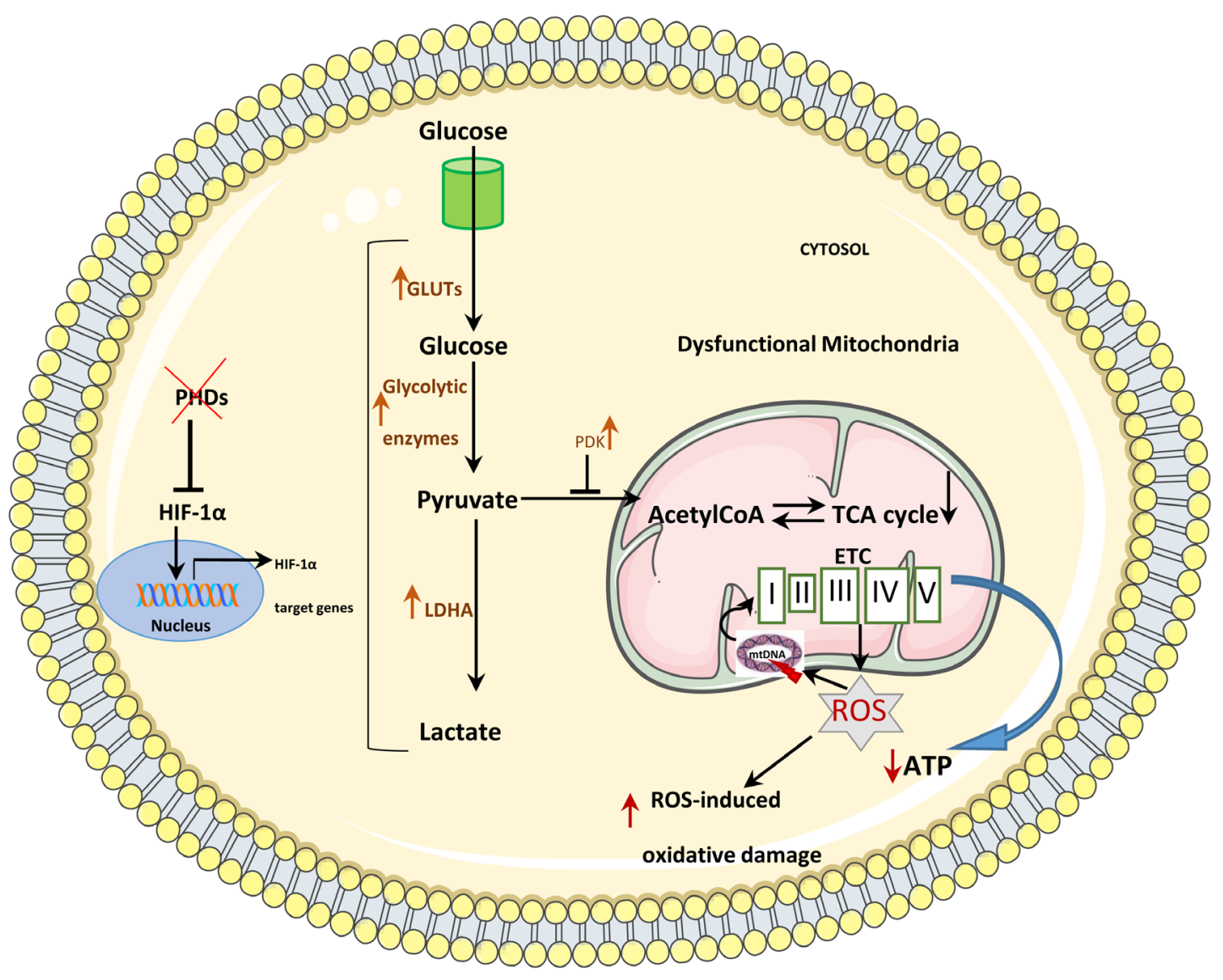

Fig. 3. Decreased oxygen levels stabilize HIF-1, which targets genes involved in hypoxic cell metabolism. HIF-1 activates glycolysis by upregulating the expression of glucose transporters (GLUTs) and glycolytic enzymes e.g. lactate dehydrogenase (LDHA) pyruvate dehydrogenase kinase (PDK). Hypoxia also increases the production of ROS leading to oxidative damage and alteration of mitochondrial and cell functions. 
diminishing pyruvate entry into the TCA cycle, subsequently decreasing mitochondrial oxidative phosphorylation. Hypoxic reprogramming of metabolism is also associated with the adaptation to excessive production of ROS, which accompanies mitochondrial dysfunctions under hypoxia (EALES et al. 2016).

\section{CARDIAC ENERGY METABOLISM DURING DEVELOPMENT AND ISCHAEMIC HEART DISEASES}

The fetal heart is adjusted to hypoxic environment and low fatty acid content, therefore fetal cardiomyocytes obtains ATP via glycolysis (LOPASCHUK and JASWAL 2010). Additionally, energy may be also produced through the process of lactate oxidation due to the elevated lactate levels. The main changes during the transition of the fetal heart into the postnatal form are associated with the increased workload and the energy demand for its growth and development. These processes cannot be met by glucose and lactate consumption, however glycolysis is still the main energy source in the immediate newborn period and by 7 days after birth glycolysis decreases providing only $10 \%$ of total ATP production (LOPASCHUK and JASWAL 2010). The postnatal environment rich in oxygen and the milk diet abundant in free fatty acids (FAs) induces a major metabolic switch of mature CM from glycolysis to oxidative metabolism (BRECKENRIDGE et al. 2013). Interestingly, this metabolic change is suggested to decline the regenerative phenotype of mature cardiomyocytes and correlates with higher number of mitochondria in cardiomyocytes (KARBASSI et al. 2020). Other metabolic pathways such as glucose, pyruvate, glycogen, lactate and triglycerides ketone bodies, can be also adopted by the adult heart as energy-providing substrates (MALANDRAKI-MILLER et al. 2018). During myocardial infarction, the hypoxic heart regions relies on glycogen, as an anaerobic fuel that serves for energy production and storage. The deprivation of oxygen results also in mitochondrial dysfunction and reduction of FAs oxidation that elevates anaerobic glycolysis and lactate production causing intracellular acidosis. In heart failure, the metabolic profile of the heart is similar to these observed in the fetal heart state, with a high dependence to glycolysis instead of mitochondrial oxidative phosphorylation (TAEGTMEYER et al. 2010).

\section{HUMAN IPSC-DERIVED CARDIOMYOCYTES (hiPSC-CMs)}

The discovery that somatic cells could be reprogrammed to a pluripotent state has profoundly changed the landscape of stem cell research. Human induced pluripotent
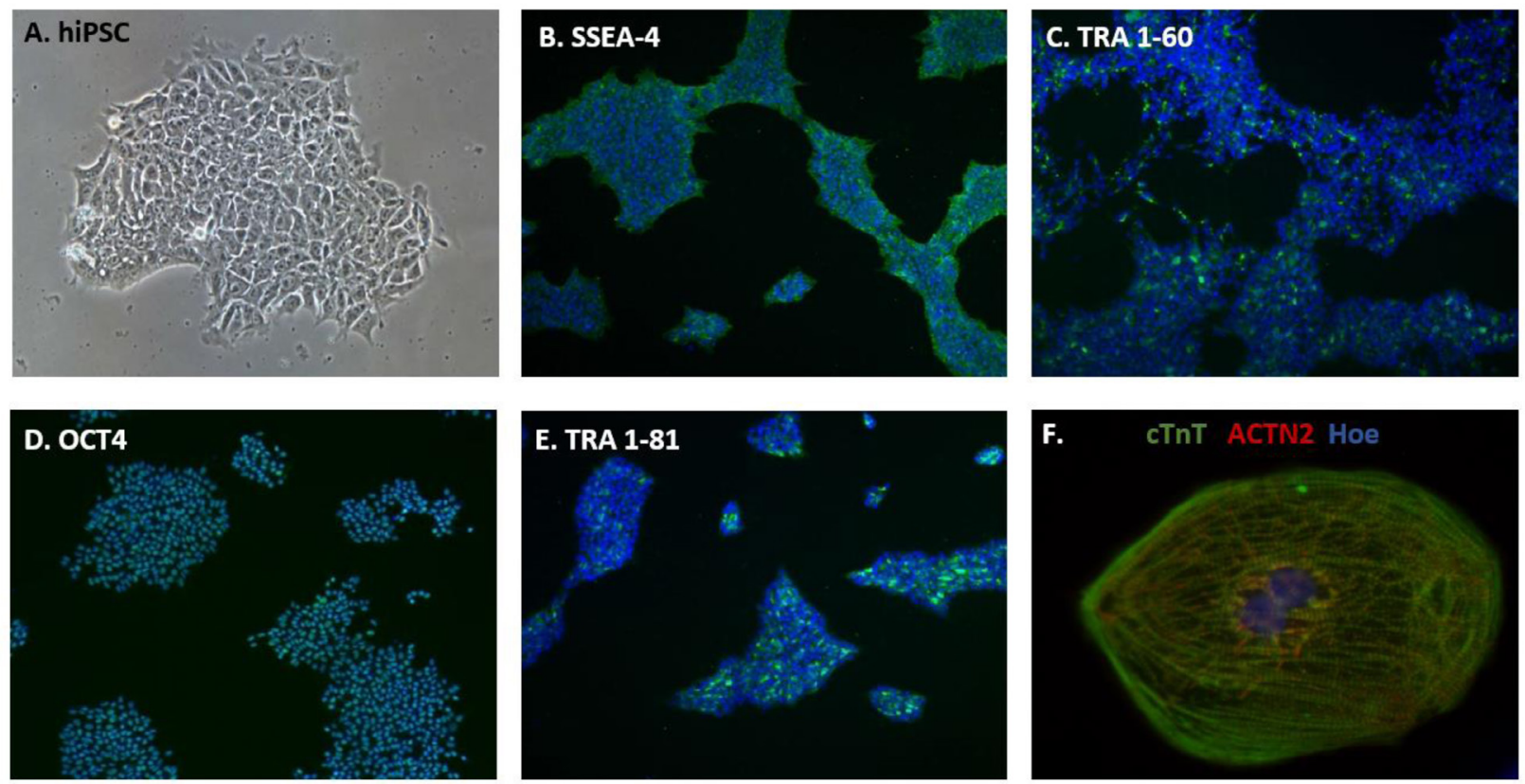

Fig. 4. Human induced pluripotent stem cell and cardiomyocytes derived from peripheral blood mononuclear cells. (A). Brightfield microscopy image of iPSC colony. (B-E). Immunofluorescence staining of pluripotency markers: OCT4, SSEA-4, TRA 1-81, TRA 1-60 in iPS cells. (F). Immunofluorescence staining of cardiac troponin $\mathrm{T}$ ( $\mathrm{CTnT}$ ) and of endogenous sarcomeric alpha actinin (ACTN2) in iPSC-CM. (Biniecka et al. unpublished data). 
stem cell (iPSCs) were first generated from dermal fibroblasts by Takahashi and Yamanaka in 2007, utilizing retroviral transduction of transcription factors Oct4, Sox2, Klf4, and c-Myc. Subsequently, the methodology for generating iPSCs has improved. Currently, the most popular method is Sendai-based reprogramming vectors based on a modified, non-transmissible form of Sendai virus $(\mathrm{SeV})$ allowing for safe and effective delivery and expression of key genetic factors necessary for reprogramming somatic cells into iPSCs.

Hypoxia has been found to facilitate the reprogramming process and iPSC generation. In the study by the Yamanaka's group (YosHIDA et al. 2009), the efficiency of iPSC generation from mouse and human fibroblasts was highly improved when reprogramming process was performed under $5 \%$ hypoxia comparing to normoxic conditions. Other study examined the role of HIF-1a and HIF-2a during the iPSC generation and found that both HIF isoforms are essential to initiate metabolic switch and for the acquisition of pluripotency, however stabilization of HIF-2a during later stages represses reprogramming (MATHIEU et al. 2014).

The pluripotent state of obtained iPS cells can be confirmed by their expression of pluripotency markers (Fig. 4) or by the formation of embryoid bodies (EBs) - three-dimensional aggregates of iPS cells. Within embryoid bodies iPS cells undergo differentiation and cell specification along the three germ lineages - endoderm, ectoderm, and mesoderm, which comprise all somatic cell types. iPSCs can be reprogrammed from many somatic cell sources e.g. fibroblasts, peripheral mononuclear blood cells, keratinocytes, or renal epithelial cells in the urine. However, in vivo teratoma formation and tetraploid complementation are the most rigorous and arguably accurate among current pluripotency methods. Teratoma formation assay provides reliable and comprehensive confirmation of 3 -germ-layer differentiation capability in vivo. Tetraploid complementation assay is conducted to compare pluripotent capability between iPSC and embryonic stem cells (ESCs). Both stem cell types are injected into tetraploid blastocysts and the resulting embryo or animal must develop in its entirety from the injected ESC or iPS cells.

Like embryonic stem cells, iPSCs have unlimited proliferation capacity and the ability to differentiate into many types of somatic cells, including human iPSC-derived cardiomyocytes (iPSC-CMs). The improvements in differentiating techniques in the past 10 years broaden the use of hiPSC de- rived $\mathrm{CM}$ (cardiomyocytes), especially in cardiac research. Initial methods for differentiating hPSCs to cardiomyocytes were associated with poor cell reproducibility and heterogeneity and relied on co-culture with endodermal stromal cells or on embryoid body differentiation. Later protocols allowed for CM generation from EBs containing defined numbers of cells, in serum-free medium in the presence of defined cytokines crucial for embryonic heart development. Subsequently, further strategies involved the two-dimensional monolayer format of hiPSCs cultivated with supplementation of growth factors as signaling cues for differentiated cardiomyocytes (DI BALDASSARRE et al. 2018). Most of the currently available protocols generate ventricular-like cardiomyocytes that can be used to model the cell-autonomous ventricular aspects of the diseases.

\section{METABOLIC CHANGES DURING REPROGRAMMING TO IPSC}

Reprogramming of somatic cells changes the energy metabolism profile towards glycolysis as the high rates of glycolysis and low oxidative phosphorylation support the rapid cell proliferation of iPSC. The reprogramming factors, such as c-Myc and Lin28, have been demonstrated to promote glycolysis, reflected by upregulation of glycolytic enzymes e.g. glucose transporter GLUT1, hexokinase (HK) and LDH in reprogrammed pluripotent stem cells. Furthermore, elevated levels of glucose-6-phosphate in hiPSCs redirect metabolism towards pentose phosphate pathway allowing for the production of reducing factor NADPH and subsequent rapid biosynthesis of FAs and nucleotides. Interestingly, efficiency of iPSC reprogramming may be enhanced by D-fructose-6- phosphate stimulated glycolysis. Hypoxia alone can also invert ESC- and iPSC-derived differentiated cells back to a stem cell-like state, by reactivation of an Oct4-promoter reporter. These cells mimic stem cells morphology and are characterized by self-renewal capacity, Oct4 promoter methylation state, the presence of pluripotency markers TRA1-60 and SSEA4, and the ability of teratoma formation in vivo (MATHIEU et al. 2013).

\section{METABOLIC MATURATION OF IPSC-CMS}

Metabolic maturation of myocardial cells is characterized by increased mitochondrial oxidative oxidation and fatty acid $\beta$-oxidation as a key energy source to meet high energy demand of the heart. Contrary, the phenotype of iPSC-CMs cultured 
in vitro maintain an immature fetal CMlike features that are different from adult CMs (SHINAGAWA et al. 2014, KARBASSI et al. 2020). It is reflected by distinct cellular structure and metabolism limiting iPSC-CMs clinical application in the field of regenerative cardiology, in vitro iPS-cellbased models of cardiac diseases and cardiotoxicity. In addition, clinical application of immature iPSC-CMs may cause arrhythmia when used for myocardial regeneration following heart failure (KNOLLMANN 2013, SAMAK and HINKEL 2019). Therefore, improving the maturation of hPSC-CMs is currently a subject of intense research and many approaches have been introduced including long-term culture, metabolic hormonal treatment, microRNA, or tissue engineering. However, the role of hypoxia and energy metabolism in promoting maturation of hPSC-CMs has not been widely investigated.

Transient hypoxia during in vitro cardiac differentiation upregulates the Wnt signaling pathway and expression of Wnt proteins, an effect lost under normoxia (MEDLEY et al. 2013). This process is associated with increased expression of cardiac markers, reduced expression of $\beta$-myosin heavy chain and a damaged development of contractile phenotype. Other study showed hypoxia-induced differentiation of ESCs towards mesoderm and endodermal lineages, while iPS cells were primed for towards ectodermal differentiation (FYNES et al. 2014). Treatment of hiPSC-CMs cardiac spheres with HIF-1a inhibitor significantly increased fatty acid oxidation and mitochondrial maximal respiration improving maturation of human iPSC-CMs (GENTILLON et al. 2019).

Further investigations on the importance of bioenergetics in the functional maturation of human pluripotent stem cell-derived CMs showed that aberrant activation of the HIF-1a/LDHA signaling pathway results in a metabolic shift toward aerobic glycolysis. This was accompanied by decreased number of mitochondria, lower levels of cellular ATP and impaired contractility. However, lack of glucose was associated with inhibition of HIF-1a and LDHA activity and subsequent repression of glycolysis followed by improvement in metabolic and functional maturation of iPSC-CMs (HU et al. 2018). Likewise, other studies have shown glucose as a negative regulator of the maturation of $\mathrm{hESC}$ $\mathrm{CMs}$ and that fatty acid-contained CM maturation medium enhanced the maturation of human iPSC-CMs by improving sarcomere organization, maturation related gene expression and enhanced contractility of iPSC-CMs (RAMACHANDRA et al. 2018, YANG et al. 2019). Another study investigated whether the energy substrate fatty acid-treated iPSC-CMs exhibit adult CM-like metabolic properties and whether fatty acid utilization could enhance the maturation of iPSC-CMs in cell structure, morphology, gene expression, and energy metabolism. The results of this report showed improved maturation of iPSC-CMs in the presence of fatty acid-rich culture medium. The matured iPSC-CMs exhibit adult CM-like metabolic phenotypes characterized by enhanced mitochondrial oxidative function associated with stem cell fate, cell proliferation and differentiation (Horikoshi et al. 2019).

In conclusion, oxygen plays a critical role in aerobic respiration and metabolism, as it acts as the final electron acceptor in the mitochondrial electron transport chain to generate ATP within eukaryotic cells and subsequently to maintain a variety of biological activities. However, limited oxygen supply in the whole body or local tissues results in hypoxia which leads to a metabolic crisis and impairment of physiological functions and viability. The Nobel awarded discovery of HIFs and their regulation by the PHD-pVHL axis has facilitated our understanding of how cells respond to hypoxia at the transcriptional level and provided potential therapeutic targets for clinical evaluation and intervention. Tissue hypoxia is one of the common features in cardiovascular diseases including heart failure, atherosclerosis and vascular remodeling and hypoxia signaling has a potential to become a therapeutic target in the managing cardiovascular regenerative medicine. Currently, iPSC-derived cardiomyocytes can be generated routinely with high yield and purity for disease modeling research and drug cardiotoxicity. Despite considerable progress in understanding the biology of iPSC-CM, a major limitation for their clinical applications is the immature state of these cardiomyocytes, which is far from the adult-like phenotype in vivo. Metabolism has emerged as a potent factor to control iPSC-CM maturation, however future work is required to identify multiple drivers of maturation and to determine appropriate cell culture conditions to create more mature cardiomyocytes for research and regenerative medicine.

\section{Summary}

The 2019 Nobel Prize in Physiology or Medicine was awarded to three physician scientists, Drs. William G. Kaelin, Jr., Peter Ratcliffe and Gregg Semenza, for their groundbreaking work revealing how cells sense and adapt to oxygen availability. Here, we summarize the history of their discoveries. Understanding the cellular adaptation to oxygen deficiency - hypoxia - has a deep impact on our knowledge of the pathogenesis of several 
conditions, including heart and inflammatory diseases, as well as tumours. HIF-1 is a transcription factor that plays an essential role in hypoxia-elicited gene responses. HIF-1 targets genes are involved in many pathways, such as cellular metabolism, survival and angiogenesis. Furthermore, hypoxia has been shown to impact the reprogramming process of somatic cells into induced pluripotent stem cell (iPSCs) and iPSC differentiation to cardiomyocytes (hiPSC-CMs). New strategies have been employed to improve the maturity of hiPSC-CMs, which includes the application of mechanistic or chemical stimuli and genetic/epigenetic manipulations. Currently, the role of hypoxia and energy metabolism in promoting maturation of hPSC-CMs is a subject of new studies.

\section{REFERENCES}

Al Tameemi W., Dale T. P., Al-Jumaily R. M. K., FORSYTH N. R., 2019. Hypoxia-modified cancer cell metabolism. Front. Cell Develop. Biol. 7, doi: 10.3389 /fcell.2019.00004.

ARMSTRONG E. J. and BISCHOFF J., 2004. Heart valve development: Endothelial cell signaling and differentiation. Circ. Res. 95, 459-470.

Di BaldassarRe A., CimetTa E., Bollini S., GAGgi G., GHINASsi B., 2018. Human-induced pluripotent stem cell technology and cardiomyocyte generation: progress and clinical applications. Cells 7, doi: 10.3390/cells7060048.

BERRA E., BENIZRI E., GinOUVE A., Ronique VolMAT V. Â., LE ROUX D. Á., POUYSSE J., GuR Â., 2003. HIF prolyl-hydroxylase 2 is the key oxygen sensor setting low steady-state levels of HIF-1a in normoxia. EMBO J. 22, 40824090.

BERRA E., GinOUVÈs A., POUYSSÉGur J., 2006. The hypoxia-inducible-factor hydroxylases bring fresh air into hypoxia signalling. EMBO Rep. 7, 41-45.

BRECKENRIDGE R. A., PiotrowskA I., NG K. E. RAGAN T. J., WEST J. A., KOTECHA S., TOWERS N., BennetT M., KIENESBERGER P. C., et al., 2013. Hypoxic regulation of hand1 controls the fetal-neonatal switch in cardiac metabolism. PLoS Biol. 11, doi: 10.1371/journal. pbio. 1001666.

BRUICK R. K., MCKNIGHT S. L., 2001. A conserved family of prolyl-4-hydroxylases that modify HIF. Science 294, 1337-1340.

CAMPBEll E. L., BRUYNinCKX W. J., Kelly C. J., Glover L. E., McNamee E. N., Bowers B. E., BAYless A. J., Scully M., et al., 2014. Transmigrating neutrophils shape the mucosal microenvironment through localized oxygen depletion to influence resolution of inflammation. Immunity 40, 66-77.

Chandel N. S., McClintock D. S., Feliciano C. E., Wood T. M., MelendeZ J. A., RodrigueZ A. M., SChumaCKer P. T., 2000. Reactive oxygen species generated at mitochondrial Complex III stabilize hypoxia-inducible factor-1a during hypoxia: A mechanism of $\mathrm{O} 2$ sensing. J. Biol. Chem. 275, 25130-25138.

Cioffi C. L., LIU X. Q., Kosinski P. A., GaraY M., BOWEN B. R., 2003. Differential regulation of HIF-1a prolyl-4-hydroxylase genes by hypoxia in human cardiovascular cells. Biochem. Biophys. Res. Commun. 303, 947-953.

Cummins E. P., BERRA E., COMERFORD K. M., GiNOUVES A., FITZGERALD K. T., SEEBALLUCK F., Godson C., Nielsen J. E., Moynagh P., POUYSSEgur J., TAYLOR C. T., 2006. Prolyl hydroxylase-1 negatively regulates I $\mathrm{K} B$ kinase- $\beta$, giving insight into hypoxia-induced $N F \kappa B$ activ- ity. Proc. Natl. Acad. Sci. USA 103, 1815418159.

Dengler V. L., Galbraith M. D., Espinosa J. M., 2014. Transcriptional regulation by hypoxia in ducible factors. Crit. Rev. Biochem. Mol. Biol. $49,1-15$

DOR Y., Klewer S. E., MCDONALD J. A., KeshET E., CAMENISCH T. D., 2003. VEGF modu lates early heart valve formatio. Anat. Record 271A, 202-208.

DURÁN R. V., OPPliger W., Robitaille A. M., Heiserich L., Skendau R., GotTlieb E., Hall M. N., 2012. Glutaminolysis activates RagmTORC1 signaling. Mol. Cell 47, 349-358.

EAles K. L., HOllinshead K. E. R., Tennant D. A., 2016. Hypoxia and metabolic adaptation of cancer cells. Oncogenesis 5, e190-e190.

ECKle T., Kohler D., Lehmann R., Kasmi K. C. E., EltZSCHIG H. K., 2008. Hypoxia-inducible factor-1 is central to cardioprotection a new paradigm for ischemic preconditioning. Circulation 118, 166-175.

Epstein A. C. R., Gleadle J. M., McNeill L. A., Hewitson K. S., O’ROURKe J., MOLE D. R., MukherJi M., Metzen E., Wilson M. I., DHANDA A., TIAN Y. M., MASSON N., et al., 2001. C. elegans EGL-9 and mammalian homologs define a family of dioxygenases that regulate HIF by prolyl hydroxylation. Cell 107, 43-54.

Fearon U., Canavan M., Biniecka M., Veale D. J., 2016. Hypoxia, mitochondrial dysfunction and synovial invasiveness in rheumatoid arthritis. Nat. Publi. Group 12, 385-397.

Fynes K., TOSTOES R., RUBAN L., WeIL B., MASON C., VERAITCH F. S., 2014. The differential effects of $2 \%$ oxygen preconditioning on the subsequent differentiation of mouse and human pluripotent stem cells. Stem Cells Develop. 23, 1910-1922.

Garvalov B. K., Foss F., Henze A. T., Bethani I., GRÄF-HÖCHST S., Singh D., FIlATOVA A., Dopeso H., SeIdel S., DAMM M., ACKer-PALMER A., ACKER T., 2014. PHD3 regulates EGFR internalization and signalling in tumours. Nat. Commun. 5, 1-11.

Gentillon C., Li D., Duan M., Yu W. M., PreinINGER M. K., JHA R., RAMPOLDI A., SARAF A., GIBSON G. C., QU C. K., BROWN L. A., XU C., 2019. Targeting HIF-1a in combination with PPARa activation and postnatal factors promotes the metabolic maturation of human induced pluripotent stem cell-derived cardiomyocytes. J. Mol. Cell. Cardiol. 132, 120-135.

GioRDANO F. J., 2005. Oxygen, oxidative stress, hypoxia, and heart failure. J. Clin. Investigat. $115,500-508$.

Glover L. E., Lee J. S., Colgan S. P., 2016. Oxygen metabolism and barrier regulation in the intestinal mucosa. J. Clin. Investigat. 126, 3680-3688.

Hara S., Hamada J., Kobayashi C., Kondo Y., ImURA N., 2001. Expression and characterization of hypoxia-inducible factor (HIF)-3a in human kidney: Suppression of HIF-mediated gene expression by HIF-3a. Biochem. Biophys. Res. Commun. 287, 808-813.

He X., Zeng H., Roman R. J. Chen J. X., 2018. Inhibition of prolyl hydroxylases alters cell metabolism and reverses pre-existing diastolic dysfunction in mice. Int. J. Cardiol. 272, 281287.

Heir P., SRIKumar T., Bikopoulos G., Bunda S., PoON B. P., LeE J. E., Raught B., OHH M., 2016. Oxygen-dependent regulation of erythropoietin receptor turnover and signaling. J. Biol. Chem. 291, 7357-7372. 
HÖLSCHER M., SCHÄFER K., KRULL S., FARHAT K., Hesse A., Silter M., Lin Y., Pichler B. J., Thistlethwaite P., El-ARmouche A., MaIER L. S., Katschinski D. M., ZiEseniss A., 2012. Unfavourable consequences of chronic cardiac HIF-1a stabilization. Cardiovasc. Res. 94, 7786.

Horikoshi Y., Yan Y., Terashvili M., Wells C., HORIKOSHI H., FUJITA S., BOSNJAK Z., BAI X., 2019. Fatty acid-treated induced pluripotent stem cell-derived human cardiomyocytes exhibit adult cardiomyocyte-like energy metabolism phenotypes. Cells 8, doi: 10.3390/ cells8091095.

Hu D., LiNDERS A., YAMAK A., CORREIA C., KIJLSTRA J. D., Garakani A., XIAO L., Milan D. J., VAN DER MEER P., SerRa M., Alves P. M., DOMIAN I. J., 2018. Metabolic maturation of human pluripotent stem cell-derived cardiomyocytes by inhibition of HIF1a and LDHA. Circul. Res. 123, 1066-1079.

Hughes B. T., EsPenshade P. J., 2008. Oxygenregulated degradation of fission yeast SREBP by Ofd1, a prolyl hydroxylase family member. EMBO J. 27, 1491-1501.

KAPITSINOU P. P., LIU Q., UNGeR T. L., RHA J., DAVIDOFF O., KeITH B., EPSTEIN J. A., MOORES S. L., ERICKSON-Miller C. L., HAASE V. H., 2010. Hepatic HIF-2 regulates erythropoietic responses to hypoxia in renal anemia. Blood $116,3039-3048$.

KaRbassi E., FENIX A., MarChIANO S., MURAOKA N., NAKAMURA K., YANG X., MuRRY C. E., 2020. Cardiomyocyte maturation: advances in knowledge and implications for regenerative medicine. Nat. Rev. Cardiol. 17, 341-359.

Keskiaho K., Hieta R., SORMunen R., MyllyHaRJU J., 2007. Chlamydomonas reinhardtii has multiple prolyl 4-hydroxylases, one of which is essential for proper cell wall assembly. Plant Cell 19, 256-269.

KNOLLMANN B. C., 2013. Induced pluripotent stem cell-derived cardiomyocytes: boutique science or valuable arrhythmia model? Circul. Res. 112, 969-976; discussion 976.

Koeppen M., Lee J. W., SeO S. W., Brodsky K. S., KRETH S., YANG I. V., BUTTRICK P. M., ECKLE T., Eltzschig H. K., 2018. Hypoxiainducible factor 2-alpha-dependent induction of amphiregulin dampens myocardial ischemiareperfusion injury. Nat. Commun. 9, 1-13.

LAGORY E. L., GIACCIA A. J., 2016. The ever-expanding role of HIF in tumour and stromal biology. Nat. Cell Biol. 18, 356-365.

LAITALA A., ERLER J. T., 2018. Hypoxic signalling in tumour stroma. Front. Oncol. 8, doi: 10.3389/fonc.2018.00189.

LeE J. W., Ko J., Ju, C., Eltzschig H. K., 2019. Hypoxia signaling in human diseases and therapeutic targets. Exp. Mol. Med. 51, 1-13.

LeE P., Chandel N. S., Simon M. C., 2020. Cellular adaptation to hypoxia through HIFs and beyond. Nat. Rev. Mol. Cell Biol. 21, 268283.

Lee S. H., Wolf P. L., Escudero R., Deutsch R., JAMIESON S. W., THISTLETHWAite P. A., 2000. Early expression of angiogenesis factors in acute myocardial ischemia and infarction. New Engl. J. Med. 342, 626-633.

LiN Q., Huang Y., BOOTH C. J., HaAse V. H., JOHNSON R. S., CELESTE SimON M., GioRdano F. J., YUN Z., 2013. Activation of hypoxia-inducible factor-2 in adipocytes results in pathological cardiac hypertrophy. J. Am. Heart Assoc. 2, doi: 10.1161/JAHA.113.000548.
LOBODA A., JOZKOWICZ A., DULAK J., 2010. HIF-1 and HIF-2 transcription factors--similar but not identical. Mol. Cells 29, 435-442.

LOBODA A., JOZKOWICZ A., DULAK J., 2012. HIF-1 versus HIF-2 - Is one more important than the other? Vasc. Pharmacol. 56, 245-251.

LOPASCHUK G. D., JASWAL J. S., 2010. Energy metabolic phenotype of the cardiomyocyte during development, differentiation, and postnatal maturation. J. Cardiovasc. Pharmacol. 56, 130-140.

Makino Y., CaO R., Svensson K., Bertilsson G., ASMAN M., TANAKA H., CAO Y., BERKENSTAM A., PoEllinger L., 2001. Inhibitory PAS domain protein is a negative regulator of hypoxia-inducible gene expression. Nature 414, 550554.

MalandRAKI-Miller S., LOPEZ C. A., Al-SiddiQI H., CARR C. A., 2018. Changing metabolism in differentiating cardiac progenitor cells - can stem cells become metabolically flexible cardiomyocytes? Front. Cardiovasc. Med. 5, doi: 10.3389 /fcvm.2018.00119.

Mathieu J., Zhang Z., Nelson A., Lamba D. A., REH T. A., WARE C., RUOHOLA-BAKER H., 2013. Hypoxia induces re-entry of committed cells into pluripotency. Stem Cells 31, 17371748.

Mathieu J., Zhou W., Xing Y., Sperber H., FerRECCIO A., AgOSTON Z., Kuppusamy K. T., MOON R. T., RUOHOla-BAKER H., 2014. Hypoxia-inducible factors have distinct and stagespecific roles during reprogramming of human cells to pluripotency. Cell Stem Cell 14, 592605.

McNeill L. A., Hewitson K. S., Gleadle J. M., Horsfall L. E., Oldham N. J., MaXwell P. H., Pugh C. W., RATCliffe P. J., Schofield C. J., 2002. The use of dioxygen by HIF prolyl hydroxylase (PHD1). Bioorg. Med. Chem. Lett. 12, 1547-1550.

MEDLEY T. L., FURTADO M., LAM N. T., IDRIZI R., Williams D., Verma P. J., Costa M., Kaye D. M., 2013. Effect of oxygen on cardiac differentiation in mouse iPS cells: Role of hypoxia inducible factor-1 and Wnt/beta-catenin signaling. PLoS One 8, doi: 10.1371/journal. pone.0080280.

Moslehi J., Rathmell W. K., 2020. The 2019 Nobel Prize honors fundamental discoveries in hypoxia response. J. Clin. Invest. 130, 4-6.

Natarajan R., SAlloum F. N., Fisher B. J., KUKREJA R. C., Fowler A. A., 2006. Hypoxia inducible factor-1 activation by prolyl 4-hydroxylase-2 gene silencing attenuates myocardial ischemia reperfusion injury. Circ. Res. 98, 133-140.

NGUYEN T. L., DURÁN R. V., 2016. Prolyl hydroxylase domain enzymes and their role in cell signaling and cancer metabolism. Int. J. Biochem. Cell Biol. 80, 71-80.

Ockaili R., NATARAJan R., SAlloum F., Fisher B. J., JONES D., Fowler A. A., KuKREJA R. C., 2005. HIF-1 activation attenuates postischemic myocardial injury: Role for heme oxygenase-1 in modulating microvascular chemokine generation. Am. J. Physiol. Heart Circ. Physiol. 289, doi: 10.1152/ajpheart.00089.2005.

Oehme F., Ellinghaus P., KolKhof P., SMith T. J., RAMAKRISHNAN S., HÜTTER J., SCHRAMM M., FLAMME I., 2002. Overexpression of $\mathrm{PH}-4$, a novel putative proline 4-hydroxylase, modulates activity of hypoxia-inducible transcription factors. Bioch. Biophys. Res. Commun. 296, 343-349. 
Petrova V., AnNicchiarico-Petruzzelli M., Melino G., Amelio I., 2018. The hypoxic tumour microenvironment. Oncogenesis 7, doi: 10.1038/ s41389-017-0011-9.

RAMACHANDRA C. J. A., MEHTA A., WONG P., JA K. P. M. M., FRITSCHE-DANIELSON R., BHAT R. V., Hausenloy D. J., KovaliK J. P., Shim W., 2018. Fatty acid metabolism driven mitochondrial bioenergetics promotes advanced developmental phenotypes in human induced pluripo tent stem cell derived cardiomyocytes. Int. J. Cardiol. 272, 288-297.

RAVEnNa L., SAlvatori L., RUSSO M. A., 2016. HIF3a: the little we know. FEBS J. 283, 9931003.

SAlHIYYAH K., SARATHCHANDRA P., LATIF N., YACOUB M. H., CHESTER A. H., 2017. Hypoxia mediated regulation of the secretory properties of mitral valve interstitial cells. Am. J. Physiol. Heart Circ. Physiol. 313, H14-H23.

SAMAK M., HinKel R., 2019. Stem cells in cardiovascular medicine: historical overview and future prospects. Cells 8, doi: 10.3390/ cells8121530.

Sano M., Minamino T., TOKO H., Miyauchi H., ORIMO M., QIN Y., AKAZAWA,H., TATENO K., KAYAMA Y., HARADA M., SHIMIZU I., ASAHARA T., HAMADA H., TOMita S., MOLKEnTiN J. D., ZOU Y., KOMURO I., 2007. p53-induced inhibition of Hif-1 causes cardiac dysfunction during pressure overload. Nature 446, 444-448.

Schaible B., Schaffer K., TAYLOR C. T., 2010. Hypoxia, innate immunity and infection in the lung. Resp. Physiol. Neurobiol. 174, 235-243.

SCHOFIELD C. J., RATClifFE P. J., 2004. Oxygen sensing by HIF hydroxylases. Nat. Rev. Mol. Cell. Biol. 5, 343-354.

SHinAGaWA M., KoBAYASHI D., GOTO M., TANAKA M., KuRIBAYASHI K., YanagihaRA N., WatanaBe N., 2014. Identification of a bacteriolysis-associated virulence factor against lung epithelial cells in Pseudomonas aeruginosa PAO-1 cell lysate. Microb. Pathogen. 75, 35-40.

Solaini G., BARACCA A., LENAZ G., SGARBI G., 2010. Hypoxia and mitochondrial oxidative metabolism. Biochim. Biophys. Acta 1797, 1171-1177.

Taegtmeyer H., Sen S., Vela D., 2010. Return to the fetal gene program: A suggested metabolic link to gene expression in the heart. Ann. NY Acad. Sci. 1188, 191-198.

Talks K. L., Turley H., GatTer K. C., MaXwell P. H., PUGH C. W., RATClifFe P. J., HARRIS A. L., 2000. The expression and distribution of the hypoxia-inducible factors HIF-1a and HIF-2a in normal human tissues, cancers, and tumor-associated macrophages. Am. J. Pathol. 157, 411-421.
TAYLOR M. S., 2001. Characterization and comparative analysis of the EGLN gene family. Gene 275, 125-132.

TAYlOR C. T., COlgan S. P., 2017. Regulation of immunity and inflammation by hypoxia in immunological niches. Nat. Rev. Immunol. 17, 774-785.

Unwith S., ZhaO H., HenNaH L., MA D., 2015. The potential role of HIF on tumour progression and dissemination. Int. J. Cancer 136, 2491-2503.

Wei H., BedJa D., Koitabashi N., Xing D., Chen J., Fox-Talbot K., Rouf R., Chen S., SteenBERgen C., HARMON J. W., DieTz H. C., GABRIELSON K. L., KASS D. A., SEMENZA G. L., 2012. Endothelial expression of hypoxia-inducible factor 1 protects the murine heart and aorta from pressure overload by suppression of TGF- $\beta$ signaling. Proc. Natl. Acad. Sci. USA 109, E841-E850.

West C. M., VAN DER Wel, H., WANG Z. A., 2007. Prolyl 4-hydroxylase-1 mediates O2 signaling during development of Dictyostelium. Development 134, 3349-3358.

Wiesener M. S., JÜrGENSEN J. S., RosenBerger C., Scholze C. K., Hörstrup J. H., WARnECKE C., Mandriota S., BEChManN I., Frei U. A., Pugh C. W., RATClifFe P. J., BACHMANN S., MAXWEll P. H., ECKARDT K. U., 2003. Widespread hypoxia-inducible expression of HIF2alpha in distinct cell populations of different organs. FASEB J. 17, 271-273.

YANG X., RodRigueZ M. L., LEONARD A., Sun L., FISCHER K. A., WANG Y., RITTERHOFF J., ZHAO L., Kolwicz S. C., PABON L., Reinecke H., SNIADECKI N. J., TIAN R., RUOHOLA-BAKER H., XU H., MurRY C. E., 2019. Fatty acids enhance the maturation of cardiomyocytes derived from human pluripotent stem cells. Stem Cell Rep. 13, 657-668.

YOSHIDA Y., TAKAHASHI K., OKITA K., ICHISAKA T., YAMANAKA S., 2009. Hypoxia enhances the generation of induced pluripotent stem cells. Cell Stem Cell 5, 237-241.

ZHANG Q., YAN Q., YANG H., WEI W., 2019. Oxygen sensing and adaptability won the 2019 Nobel Prize in Physiology or medicine. Genes Dis. 6, 328-332.

ZhaO H. X., Wang X. L., Wang Y. H., Wu Y., LI X. Y., LV X. P., ZHAO Z. Q., ZHAO R. R., LIU H. R., 2010. Attenuation of myocardial injury by postconditioning: Role of hypoxia inducible factor-1a. Basic Res. Cardiol. 105, 109-118. 
KOSMOS Vol. 69, 4, 563-577, 2020

\author{
MONIKA BINIECKA ${ }^{1,2}$, JAN WOLNIK ${ }^{1,2}$, JÓZEF DULAK ${ }^{2}$
}

${ }^{1}$ Kardio-Med Silesia, Marii Skłodowskiej-Curie 10C, 41-800 Zabrze, ${ }^{2}$ Zakład Biotechnologii Medycznej, Wydział Biochemii, Biofizyki i Biotechnologii, niwersytrt Jagielloński,Gronostajowa 7, 30-387 Kraków, e-mail: monika.biniecka@uj.edu.pl

\title{
ODKRYCIE MECHANIZMÓW ADAPTACJI KOMÓREK DO WARUNKÓW NIEDOTLENIENIA: ROLA HIPOKSJI W ROZWOJU CHORÓB SERCA I DOJRZEWANIU KARDIOMIOCYTÓW
}

\section{Streszczenie}

W 2019 roku Nagrodę Nobla w dziedzinie fizjologii/medycyny przyznano trzem naukowcom-doktorom, dr. Williamowi G. Kaelinowi, Jr., Peterowi Ratcliffowi i Greggowi Semenza, za odkrycie mechanizmów odpowiedzialnych za dostosowywanie się komórek do dostępności tlenu. Poznanie zdolności adaptacyjnych komórek do warunków niedoboru tlenu - niedotlenienia/hipoksji - ułatwia zrozumienie podłoża wielu chorób, w tym chorób serca, układu immunologicznego oraz nowotworów. Centralnym komponentem odpowiedzi komórki na brak tlenu jest czynnik transkrypcyjny HIF-1, który aktywuje ekspresję genów zwiazanych m. in. z metabolizmem, apoptoza, czy angiogeneza. Ponadto wykazano, że hipoksja usprawnia proces reprogramowania komórek somatycznych do indukowanych pluripotencjalnych komórek macierzystych (iPSC) i ich różnicowania do kardiomiocytów. Na stopnień dojrzałości kardiomiocytów pozyskanych drogą różnicowania z iPSC wpływ mogą mieć manipulacje genetycznych/epigenetycznych bądź zastosowanie bodźców mechanicznych lub chemicznych. Ponadto, ostatnie badania wskazuja na rolę hipoksji i metabolizmu energetycznego w regulacji procesu dojrzewania hPSC-CM.

Słowa kluczowe: czynniki indukowane hipoksja, hypoxia, indukowane pluripotencjalne komórki macierzyste, kardiomiocyty z indukowanych pluripotencjalnych komórek macierzystych 